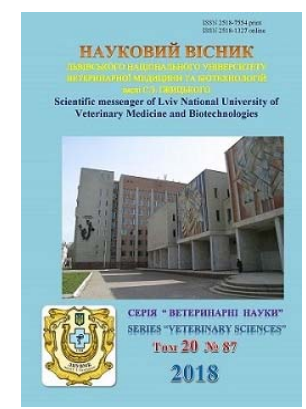

\author{
Науковий вісник Дьвівського національного університету \\ ветеринарної медицини та біотехнологій імені С.З. Гжицького
}

\author{
Scientific Messenger of Lviv National University \\ of Veterinary Medicine and Biotechnologies
}

\title{
Morphological features and morphometric indices of the mucous membranes of different parts of the intestines of broiler chickens for feeding feeds with probiotic additive
}

\author{
G. Kotsyumbas, A. Kostyniuk, V. Lemishevskyi, Yu. Fedyk \\ Stepan Gzhytskyi National University of Veterinary Medicine and Biotechnologies Lviv, Ukraine
}

Article info

Received 26.02.2018 Received in revised form 26.03 .2018

Accepted 29.03.2018

Stepan Gzhytskyi National University of Veterinary Medicine and Biotechnologies Lviv, Pekarska str., 50, Lviv, 79010, Ukraine. Tel.:+38-067-725-72-17 E-mail:catdok@ukr.net, anastasija.kostunyk@gmail.com, kotsymbas.galyna@gmail.com, info@vetpathology.lviv.ua
Kotsyumbas, G., Kostyniuk, A., Lemishevskyi, V., \& Fedyk, Yu. (2018). Morphological features and morphometric indices of the mucous membranes of different parts of the intestines of broiler chickens for feeding feeds with probiotic additive. Scientific Messenger of Lviv National University of Veterinary Medicine and Biotechnologies. 20(87), 98-106. doi: 10.15421/nvlvet8720

The article presents the results of histological, histochemical searches and histomorphometric indices of villous height, depth of the crypt of the mucous membrane of the duodenum, jejunum and caecum of broiler chickens, fed a feed with probiotic additive «Probion forte» at a dose of $1 \mathrm{~g} / \mathrm{kg}$ for 42 days in a row. The experiments were carried out on broiler chickens of the «Kobb-500» breed under vivarium conditions. Two experimental groups of broiler chickens were formed, with a body weight of 37-40 g, with 30 heads in each: First group was received feed with the probiotic «Probion forte» at a dose of $1 \mathrm{~g} / \mathrm{kg}$, and the secondcontrol group, which was fed the main ration without the addition of any preparation. At 15, 30 and 42 days of the experiment, 10 chicks from each group were withdrawn from the experiment, an autopsy was carried out and samples from the duodenum, jejunum and the i caecum were taken, which were fixed in $10 \%$ neutral formalin solution, Carnoua and Buena liquid, followed by paraffin filling. Gisto-cutters were made, stained with hematoxylin-eosin, by Stidman and McManus. For the histological, histochemical, histomorphometric search of the mucous membrane of the duodenum, jejunum and caecum of chickens of the experimental group, It was established that the use of «Probion forte» in a dose of $1 \mathrm{~g} / \mathrm{kg}$ with food for chicken broilers in the process of growth and development was contributed to: activation of the mitotic and synthesizing functions of cells, active hyperplastic and hypertrophic processes in the structural elements of the mucous membrane of the investigated sections of the intestines of broiler chickens, as a result of which was expressed by an increase in the height of the villi and the depth of the crypts. In the broiler chickens of the experimental group it was most likely increased the height of the villi in the duodenum at 15 and 42 days; in the jejunum, the probable increase in the height of the villi was noted at 15 and 30 days, and in the caecum at 30 and 42 days of the experiment. At the same time, the height of columnar epitheliocytes, which was located on the villi of the jejunum of animals of the I group, was $31.5 \mu \mathrm{m}$ and $24.9 \mu \mathrm{m}$ in control. At the same time, active formation of mucus-like cells of the duodenum, jejunum and caecum, rich in glycosaminoglycans and glycoproteins, has been established, which contributed to the formation of a thick mucosal biofilm. The latter serves as a liquid phase in which the movement of cells is carried out, as well as an important barrier to the action of enzymes, pathogens and conditionally pathogenic microorganisms. An increase in the number of columnar epithelial cells and cello-like cells of the villi of the intestinal mucus was aimed at improving parietal digestion, absorption and enhancement of the protective function.

Key words: chicken broilers, probiotic supplements, duodenum, jejunum, caecum, villi, crypt, cello-like cells, histostructure, histochemistry.

\section{Морфологічні особливості та морфометричні показники слизової оболонки різних відділів кишечнику курей-бройлерів за згодовування кормів 3 пробіотичною добавкою}

Г.І. Коцюмбас, А.К. Костинюк, В.М. Лемішевський, Ю.Я. Федик 
Львівський національний університет ветеринарної медицини та біотехнологій імені С.3. Гжицького, м. Львів, Україна

У статті наведено результати гістологічних, гістохімічних досліджень та гістоморфометричних показників висоти ворсинок, глибини крипт слизової оболонки дванадиятипалої, порожньої та сліпих кишок курей-бройлерів, яким згодовували комбікорм з пробіотичною добавкою «Probion forte» в дозі 1 г/кг 42 доби поспіль. Дослід проводили на курчатах-бройлерах породи «Коьb-500» в умовах віварію. Було сформовано дві дослідні групи курей-бройлерів, масою тіла 37-40 г, по 30 голів у кожній: І група отримувала корм з пробіотиком «Probion forte» у дозі 1 г/кг, II -контрольна група, якій згодовували основний раціон без додавання будь яких препаратів. На 15, 30 і 42 доби досліду по 10 курчат з кожної групи виводили з експерименту, проводили розтин і відбирали взіриі дванадиятипалої, порожньої та сліпих кишок, які фіксували у 10\% розчині нейтрального формаліну, рідині Карнуа та Буена з наступною заливкою у парафін. Виготовляли гістозрізи, фарбували гематоксилін-еозином, за Стідменом та Мак-Манусом. За гістологічного, гістохімічого, гістоморфометричного дослідження слизової оболонки дванадиятипалої, порожньої та сліпих кишок курей дослідної групи встановлено, шчо застосування «Probion forte» в дозі 1 г/кг з кормом курам-бройлерам у прочесі росту та розвитку сприяло: активізаціі мітотичної та синтезувальної функиї клітин, активним гіперпластичним та гіпертрофічним прочесам в структурних елементах слизової оболонки досліджуваних відділів кишок курей-бройлерів, як наслідок виразилось збільшенням висоти ворсинок та глибини крипт. У курей-бройлерів дослідної групи найвірогідніше збільшувалась висота ворсинок у дванадиятипалій кишиі на 15 i 42 доби; у порожній кишщі вірогідне збільшення висоти ворсинок відзначали на 15 i 30 доби, а у сліпих кишках - на 30 і 42 доби досліду. При цььому також зростала висота стовпчастих епітеліочитів, які розмішувались на ворсинках порожньої кишки тварин I групи, яка становила - 31,5 мкм, а у контролі - 24,9 мкм. Разом з тим встановлено активне утворення келихоподібними клітинами дванадиятипалої, порожньої та сліпих кишок слизу, багатого глікозаміногліканами та глікопротеїнами, щуо сприяло утворенню густої слизистої біоплівки. Остання слугує рідкою фазою в якій здійснюється рух клітин, а також є важливим бар 'єром від дії ферментів, патогенних та умовно-патогенних мікроорганізмів. Збільшення кількості стовпчастих епітеліоцитів і келехоподібних клітин ворсинок слизової оболонок кишечнику було направлено на покращення пристінкового травлення, всмоктування та посилення захисної функиї.

Ключові слова: кури-бройлери, пробіотичні добавки, дванадчятипала, порожня, сліпі кишки, ворсинки, крипти, келихоподібні клітини, гістоструктура, гістохімія

\section{Вступ}

На сьогоднішній день, при вирощуванні птиці широко використовують різноманітні пробіотичні кормові добавки, які містять живі мікроорганізми, що пов'язані з нормофлорою кишечника. Застосування їх грунтується на можливості заселення кишечника мікроорганізмами, які за рахунок антагоністичних властивостей, пригнічують ріст патогенних та умовнопатогенних бактерій (Gibson and Roberfroid, 1995; Cummings and Macfarlane, 2002). В процесі еволюції між живим організмом та мікробним світом склалися певні паритетні відносини, які дозволяють їм співіснувати, доповнюючи та допомагаючи один одному (Gardiner et al., 1993; Boiko, 2008). Найбільш сприятливим місцем для такого співіснування став шлунково-кишковий тракт. Він є відкритою системою, за допомогою якої здійснюється контакт макроорганізму 3 зовнішнім середовищем та мікроорганізмами, які в ньому знаходяться. Саме в кишечнику знаходять сприятливі умови понад 500 видів різних бактерій (Samarcev et al., 2007).

Найбільш функціонально активною частиною кишкової стінки, у якій відбуваються складні фізіологічні, біохімічні процеси перетравлення та всмоктування поживних речовин, є слизова оболонка, а живі мікроорганізми нормофлори кишок, що активно беруть участь в обмінних процесах є своєрідними антигенами, які позитивно впливають на стан слизової оболонки, а також стимулюють в них розвиток імунних утворень (Garmaeva, 2011).

Метою нашої роботи було вивчити гістологічні, гістохімічні особливості та морфометричні показники ворсинок і крипт слизової оболонки дванадцятипалої, порожньої і сліпих кишок курей-бройлерів, яким згодовували комбікорми 3 пробіотичною кормовою добавкою «Probion forte» в дозі 1 г/кг 42 доби поспіль.

\section{Матеріал і методи досліджень}

Дослід проводили на курчатах-бройлерах породи «Kobb-500» в умовах віварію. Було сформовано дві дослідні групи курей-бройлерів, масою тіла 37-40 г, по 30 голів у кожній. Птиця утримувалась напольно 3 вільним доступом до води та їжі. Кури I групи отримували комбікорм 3 пробіотичною добавкою «Probion forte» в дозі 1 г/кг корму поспіль 42 дні, а птиці контрольної групи (II група) згодовували збалансований комбікорм без пробіотичної добавки.

На 15, 30 та 42 добу досліду по 10 курей-бройлерів 3 кожної групи зважували, виводили з експерименту, проводили розтин і відбирали взірці дванадцятипалої, порожньої і сліпих кишок, які фіксували у 10 \% нейтральному розчині формаліну, рідині Карнуа і Буена, зневоднювали у висхідному ряді спиртів з наступною заливкою у парафін за загальноприйнятою методикою (Merkulov, 1961; Lilli, 1969; Horalskyi et al., 2005). I3 парафінових блоків виготовляли гістозрізи на санному мікротомі МС-2, товщиною 5-7 мкм. Для фарбування гістозрізів використовували загальноприйняті та спеціальні гістохімічні методики: гематоксилін та еозин, глікозаміноглікани виявляли альциановим синім за Стідманом, глікопротеїни - за Мак-Манусом. Проводили морфометричне дослідження, зокрема, визначали висоту ворсинок, глибину крипт та їх співвідношення. Світлову мікроскопію та фотографування проводили за допомогою мікроскопа Leica DM2500 (Switzerland) та фотокамери Leica DFC450C i програмного забезпечення Leica Application Suite Version 4.4. Статистичну обробку, одержаних результатів, проводили на ПК за допомогою програми Microsoft Excel. Достовірність різниці між статистичними характеристиками двох експериментальних сукупностей даних визначали за коефіцієнтом Стью- 
дента, а вірогідними вважали зміни при рівні значущості $\mathrm{P}<0,05$ (Avtandilov, 1990).

\section{Результати та їх обговорення}

Маса патраної тушки на 42 добу вирощування курей-бройлерів I групи була вищою на 275 г. і становила $1623 \pm 16,6$ г, а в контрольної птиці - 1348,7 г. Забійний вихід птиці I групи перевищував показник контрольної групи на 5\% .

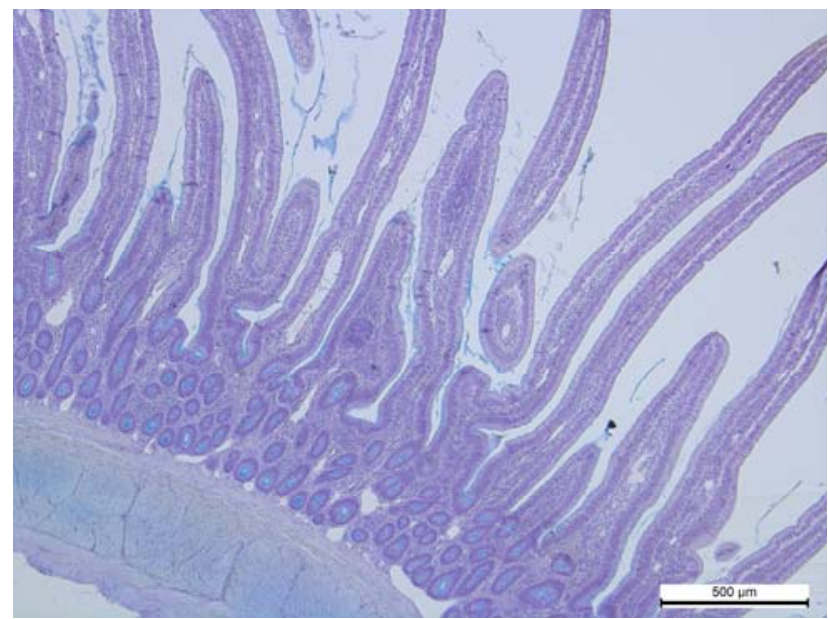

Рис. 1. Ворсинки дванадцятипалої кишки курей контрольної групи. Гематоксилін та еозин. Ок. 10 , об. 10

Світлооптичні дослідження узгоджувались 3 морфометричними показниками. У процесі росту і розвитку птиці встановлено, що ворсинки слизової оболонки досягали найбільшої висоти на 15 добу. У цей період, у курчат I групи, висота ворсинок становила 1676 мкм, що на 225 мкм більше, ніж у курчатбройлерів контрольної групи. При цьому глибина крипт дванадцятипалої кишки курчат-бройлерів I групи становила 190,5 мкм, тобто збільшувалась на 43 мкм. На 30 добу в дванадцятипалій кишці курчат-
За світлооптичного дослідження гістопрепаратів дванадцятипалої кишки, забарвлених гематоксиліном та еозином, відзначали, що ворсинки слизової оболонки контрольної так і дослідної груп довгі, пальцевидної форми, добре структуровані. Вкриті циліндричним епітелієм, видовженої форми ворсинки чітко контуровані. При цьому, в дослідній групі ворсинки слизової оболонки виглядали довші та більш щільно прилягали одна до одної. (рис. 1, рис. 2)

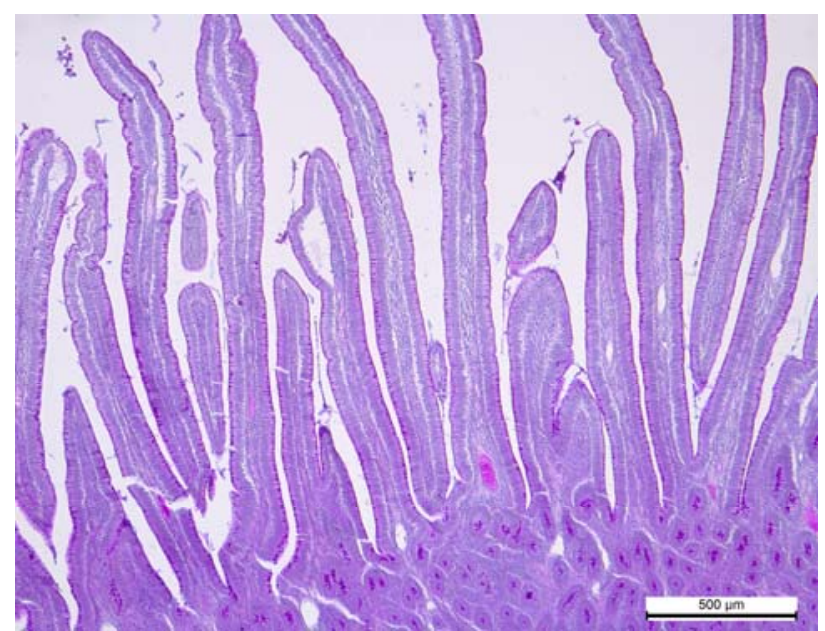

Рис. 2. Ворсинки дванадцятипалої кишки курей дослідної групи. Гематоксилін та еозин.Ок. 10, об. 10

бройлерів у порівнянні, з 15 добою, відзначали незначне зменшення висоти ворсинок як в контрольній так I групі птиці. Однак, досліджуваний показник у I групі був вищим і сягав 1321 мкм, а курей-бройлерів контрольної групи - 1041 мкм. Окрім того, на 42 добу курей-бройлерів I дослідної групи відзначали збільшення висоти ворсинок і глибини крипт дванадцятипалої кишки курчат, де висота ворсинок становила 1553 мкм, а в контрольній групі - 1370 мкм (рис. 3).

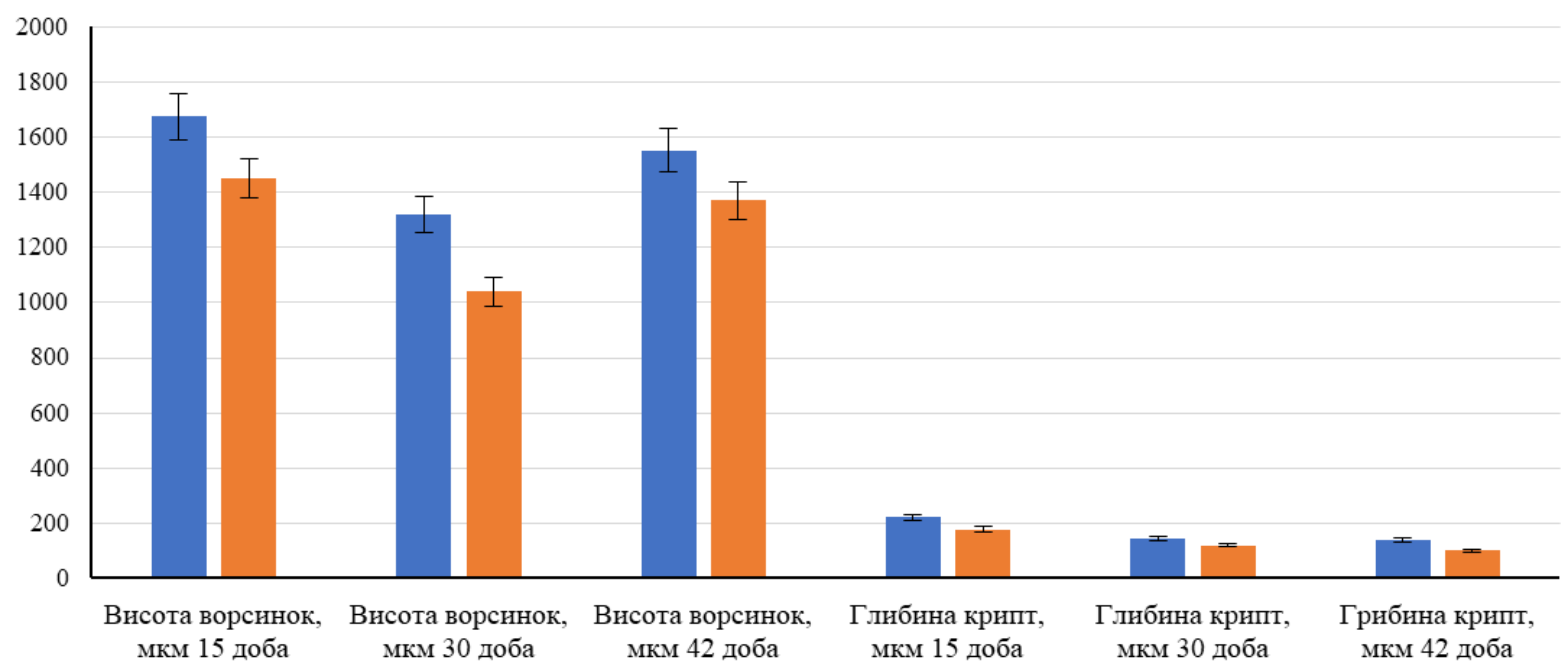

Рис. 3. Гістоморфометричні показники висоти ворсинок та глибини крипт слизової оболонки дванадцятипалої кишки на 15, 30 і 42 добу росту і розвитку курей-бройлерів контрольної і дослідної групи 
Зрозуміло, що у процесі збільшення висоти ворсинок 12-палої кишки курчат дослідної групи, зростала кількість стовпчастих епітеліоцитів, кишкових ендокриноцитів та келихоподібних клітин. Адже активний процес травлення і всмоктування здійснюється саме стовпчастими клітинами. Крім того, виявляли збільшення кількості на об'єму келихоподібних клітин у ворсинках та криптах слизової оболонки дванадцятипалої кишки курей I групи.

На гістозрізах, забарвлених за Стідменом та МакМанусом, добре проглядалась локалізація, форма, насиченість барвниками келихоподібних клітин ворсинок та крипт і відмінність між ними в дослідній та

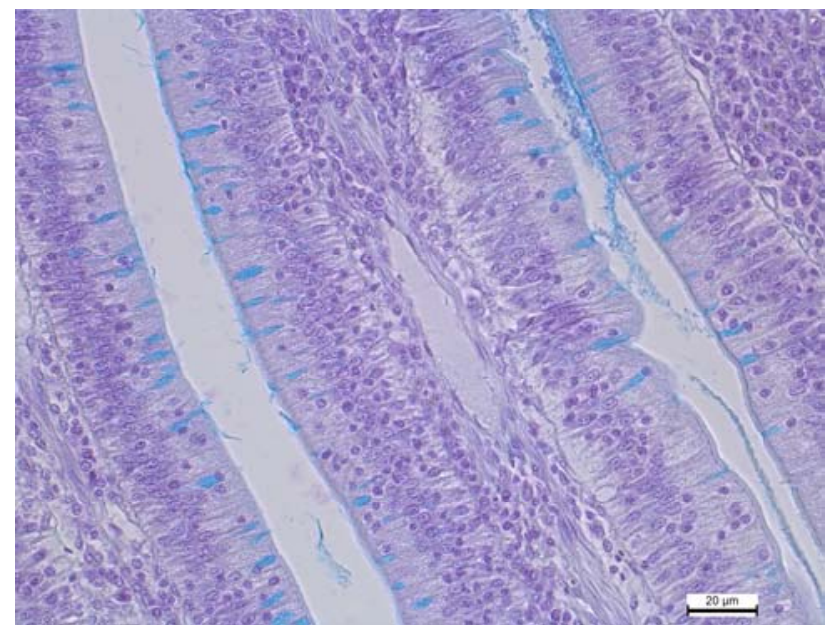

Рис. 4. Ворсинки дванадцятипалої кишки курей контрольної групи. Альціанофільні, видовженої форми келихоподібні клітини.

Альціановий синій за Стідменом. Об. 10, ок. 20

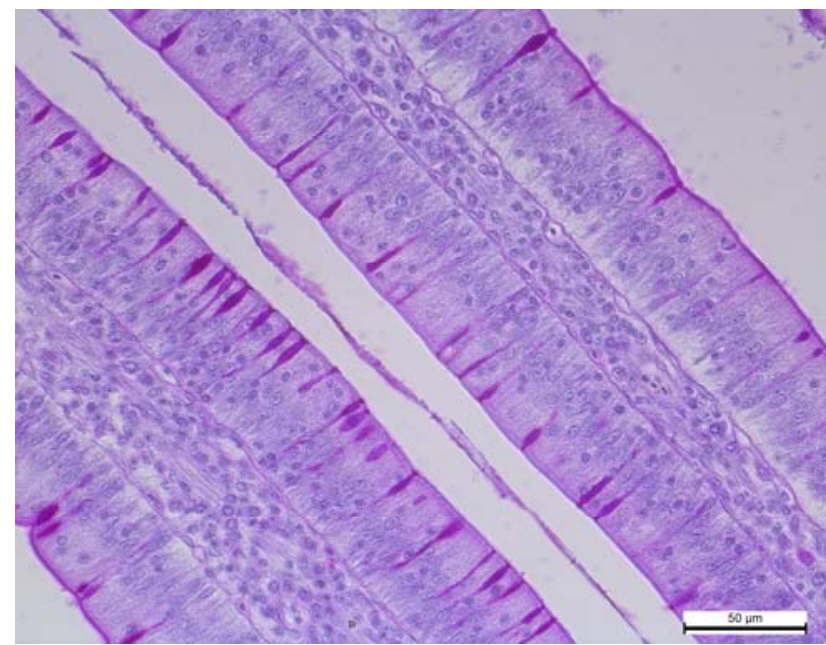

Рис. 6. Ворсинки дванадцятипалої кишки курей контрольної групи. ШИК-позитивна реакція келихоподібних клітин. Мак-Манус. Об. 10., ок. 20

За світлооптичного вивчення стінки порожньої кишки курей як в контрольних, так і дослідних груп, чітко проглядали видовженої листовидної форми ворсинки. Слід зазначити, що порівняно 3 контроль- контрольних групах. Келихоподібні клітини як у ворсинках, так і у криптах дванадцятипалої кишки курейбройлерів I груп на препаратах забарвлених за Стідменом, порівняно з контролем - траплялися частіше, були об'ємнішими, округлішої форми та інтенсивнішого голубувато-синього (альціанофільного) забарвлення, що свідчило про зростання вмісту в муцині глікозаміногліканів (рис. 4 і 5).

На препаратах, забарвлених за Мак-Манусом та Стідменом, келихоподібні клітини набували відповідно насиченого малинового кольору забарвлення, що вказувало на вміст у секреті клітин глікопротеїнів (рис. 6 i 7).

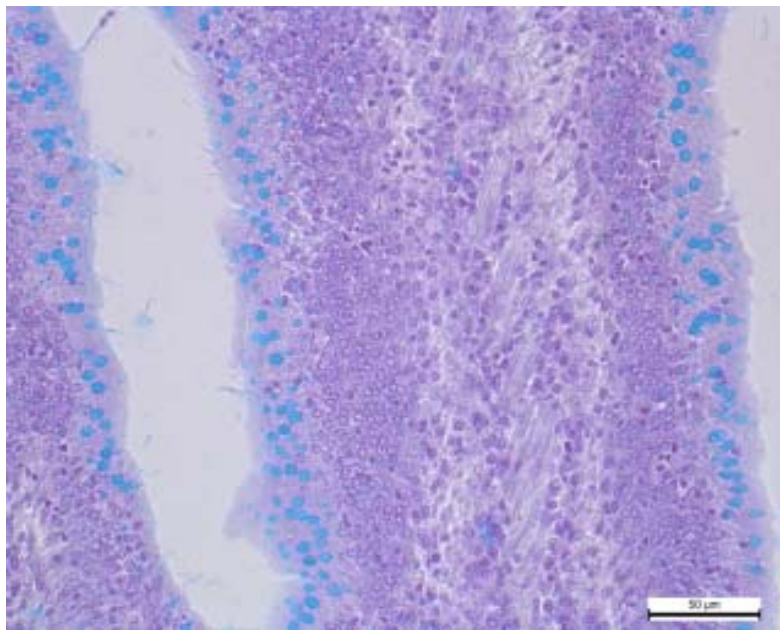

Рис. 5. Ворсинки дванадцятипалої кишки курей дослідної групи. Зростання вмісту глікозаміногліканів у келихоподібних клітинах.

Альціановий синій за Стідменом. Об. 10, ок. 20

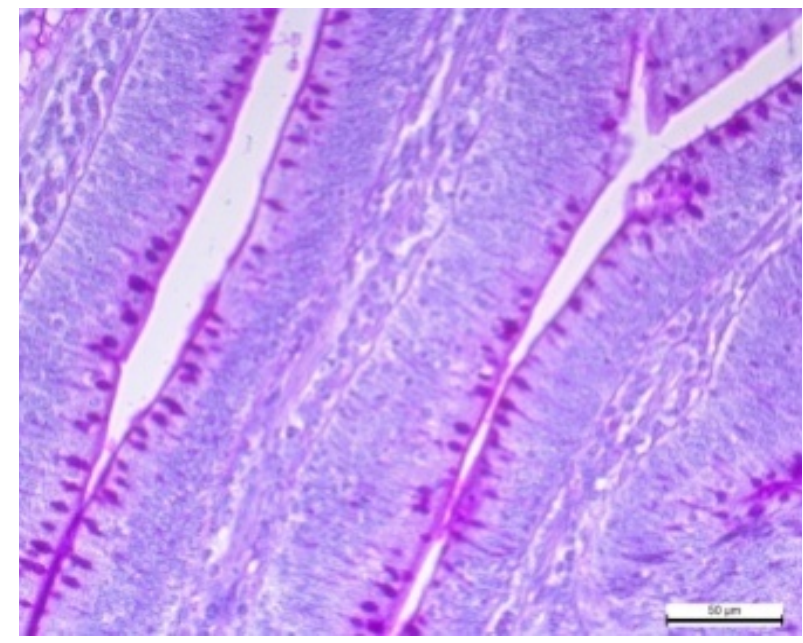

Рис. 7. Ворсинки дванадцятипалої кишки курей дослідної групи. Зростання вмісту глікопротеїнів у келихоподібних клітинах. Мак-Манус. Об. 10., ок. 20

ною групою, висота ворсинок була відносно більшою, а також простежувалось густіше їх розміщення у слизовій оболонці порожньої кишки курей дослідної групи. 


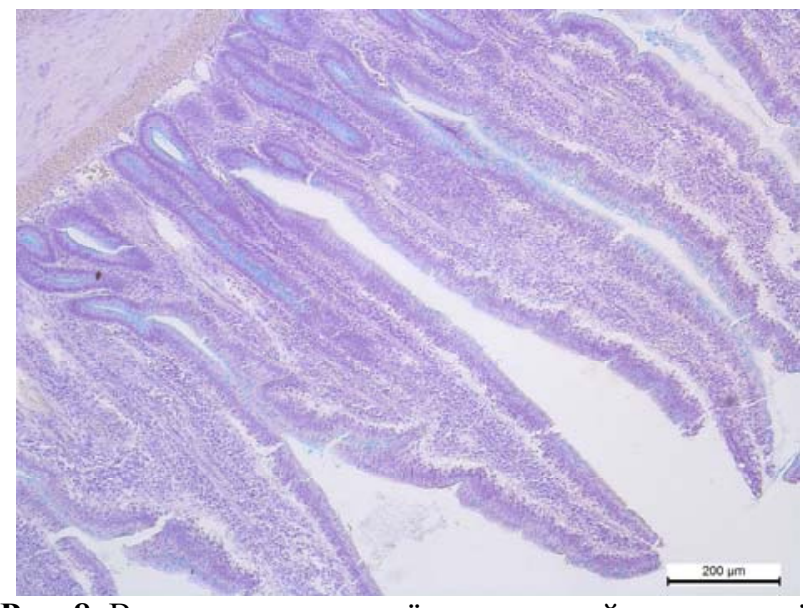

Рис. 8. Ворсинки порожньої кишки курей контрольної групи. Альціановий синій за Стідменом. Ок. 10, об. 10

Виявлені за світлооптичного дослідження мікроструктурні особливості слизової оболонки порожньої кишки дослідних груп підтверджені гістоморфометричними дослідженнями. Морфометрично встановлено, що на 15 добу досліду в курей I групи висота ворсинок становила 1596,6 мкм, тобто достовірно збільшувалась на 306,2 мкм, а глибини крипт становили 215,9 мкм, що на 25,4 мкм більше ніж у курей контрольної (II) групи. У контрольній групі висота ворсинок складала 1296,7 мкм, а глибана крипт - 190,5 мкм. На 30 добу відзначали незначне

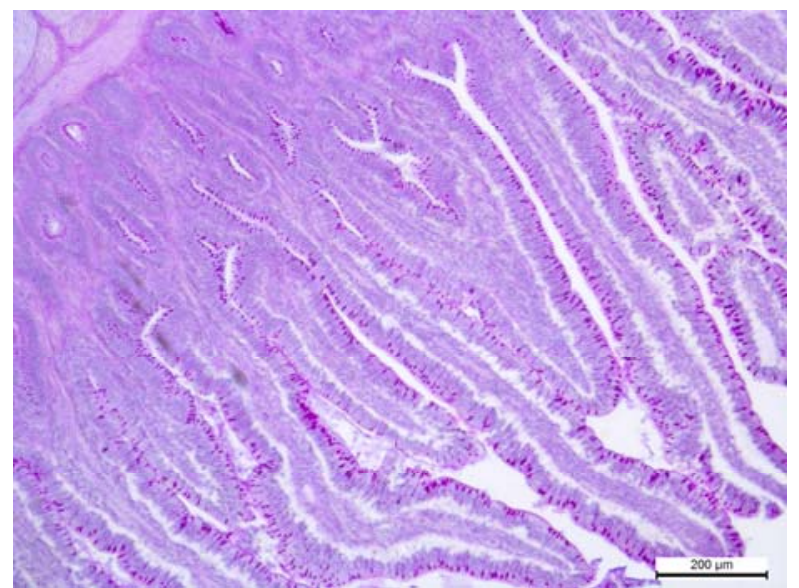

Рис. 9. Ворсинки порожньої кишки курей дослідної групи. Мак-Манус. Ок. 10, об. 10

зменшення висоти ворсинок порожньої кишки, порівняно 315 добою. Проте, порівняно 3 контрольною групою, на 30 добу досліду висота ворсинок курей I групи зростала на 338 мкм і становила1296,7 мкм, а у курей контрольної групи - 958,7 мкм. Якщо на 15 і 30 доби у курей-бройлерів I і II групи відзначали достовірне зростання висоти ворсинок слизової оболонки, то на 42 добу простежувалось їх тенденційне збільшення. У цей період висота ворсинок порожньої кишки зростала на 20,3 мкм і становила 1199,3 мкм, а в контрольній групі - 1179,0 мкм (рис. 10).

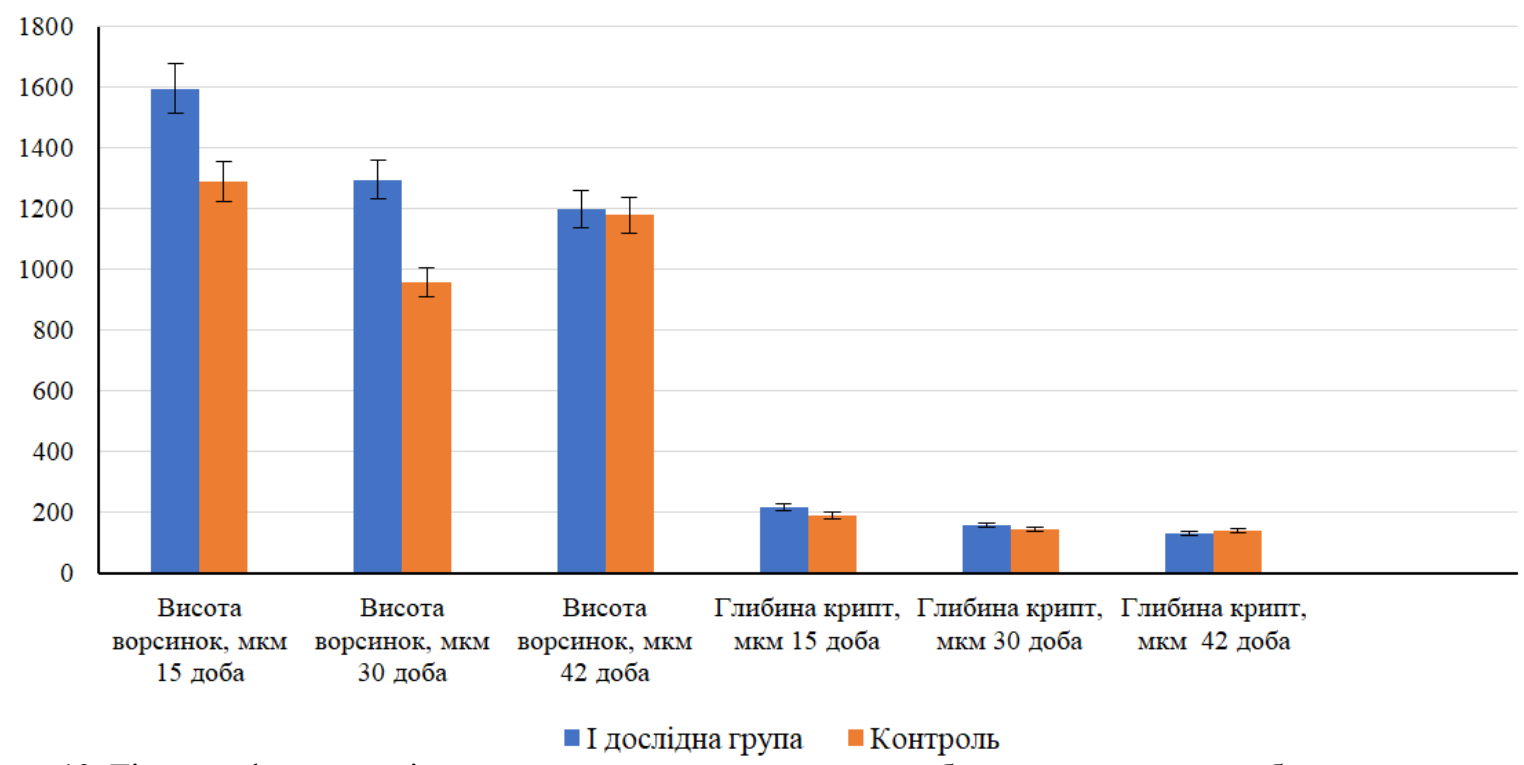

Рис. 10. Гістоморфометричні показники висоти ворсинок та глибини крипт слизової оболонки порожньої кишки на 15, 30 і 42 добу росту і розвитку курей-бройлерів контрольної і дослідної групи

Разом з тим відзначали збільшення і самих епітеліальних клітин ворсинок. Циліндричний епітелій ворсинок слизової оболонки порожньої кишки курей I групи відносно високий і за гістоморфометричного дослідження становив - 31,5 мкм, а у контролі 24,9 мкм, що вказувало на збільшення самих клітин. На препаратах, забарвлених за Мак-Манусом та альціановим синів за Стідменом чітко вирізнялись серед епітеліальних клітин ворсинок та крипт келихоподібні екзокриноцити. Якщо у ворсинках порожньої кишки курей контрольної групи келихоподібні клітини були переважно видовженої форми, то у дослідній (I) групі, клітини набували округлої форми і були дещо більшими (рис. 11 і 12).

Аналогічнічні відмінності в келихоподібних клітинах ворсинок слизової оболонки порожньої кишки курей I групи відзначали і на препаратах, забарвлених за Мак-Манусом. У дослідній групі екзокриноцити набували темно-малинового забарвлення, що вказувало на інтенсивне насичення їх PAS-позитивними 
речовинами. Активне утворення келихоподібними клітинами слизу, багатого глікозаміногліканами та глікопротеїнами сприяло утворенню щільної слизистої біоплівки на поверхні слизової оболонки (рис. 13 і 14).

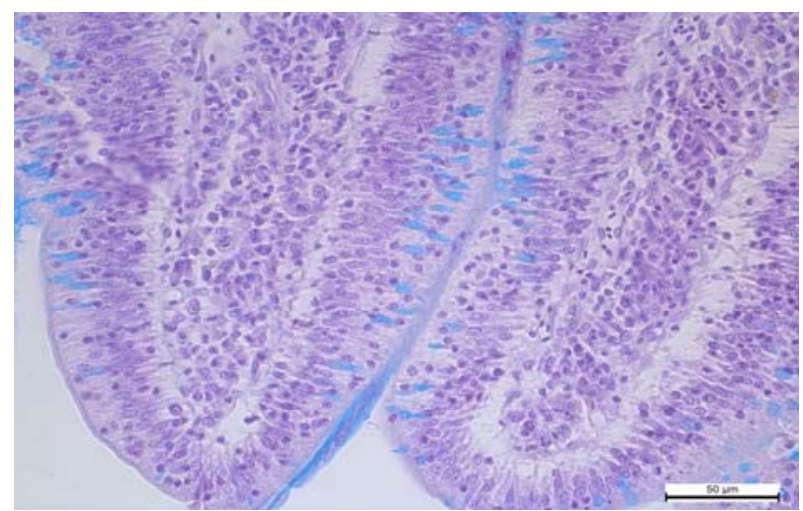

Рис. 11. Ворсинки порожньої кишки курей контрольної групи. Альціанофільність келихоподібних клітин.

Альціановий синій за Стідменом. Об. 10., ок. 40

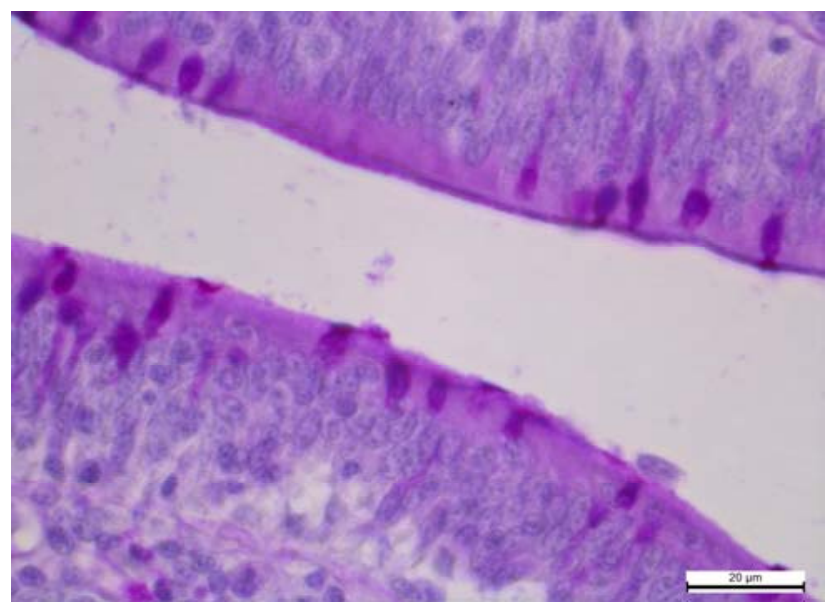

Рис. 13. Ворсинки порожньої кишки курей контрольної групи. ШИК-позитивна реакція келихоподібних клітин. Мак-Манус. Об. 10., ок. 20

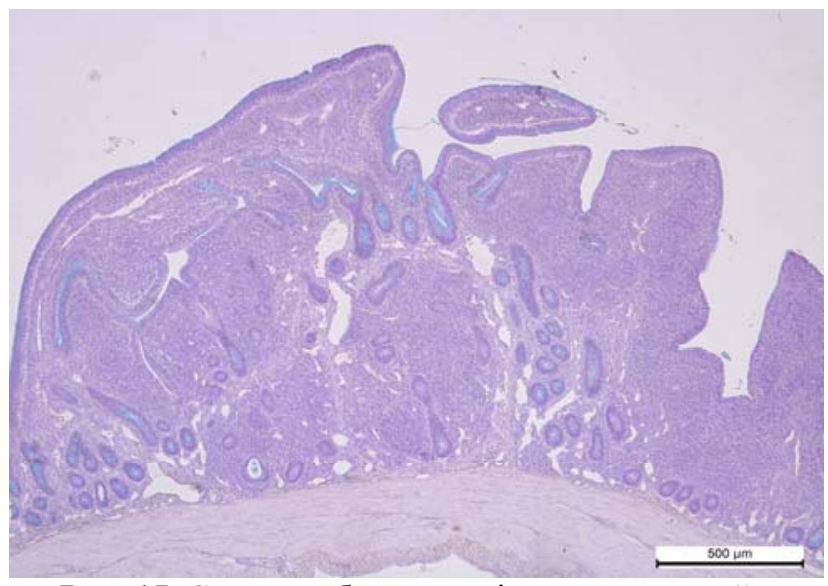

Рис. 15. Слизова оболонка сліпої кишки курейбройлерів контрольної групи. Стідмен. Ок. 10, об. 10
За світлооптичного дослідження слизової оболонки сліпих кишок курей-бройлерів дослідних груп також відзначали, що порівняно із контрольною групою, ворсинки слизової оболонки сліпих кишок вищі та відносно ширші, а розміщені в їх основі лімфоїдні вузлики густо заселені лімфоцитами (рис. 15 і 16).

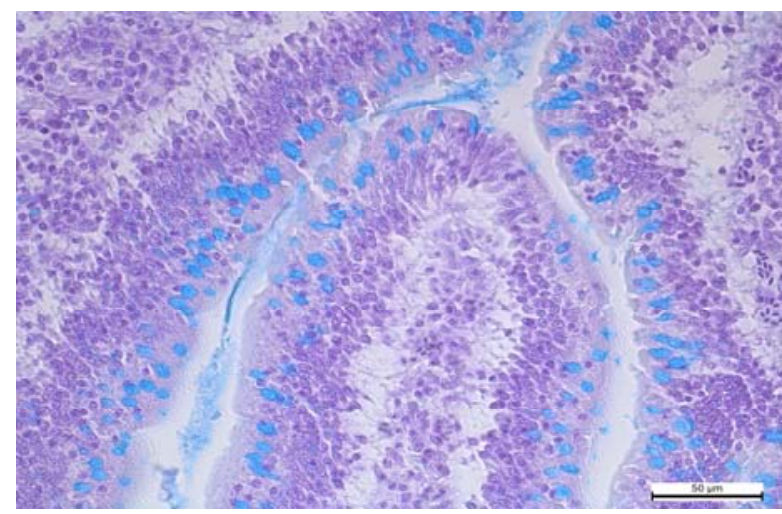

Рис. 12. Ворсинки порожньої кишки курей контрольної групи. Зростання вмісту глікозаміногліканів у келихоподібних клітинах. Альціановий синій за Стідменом. Об. 10., ок. 40

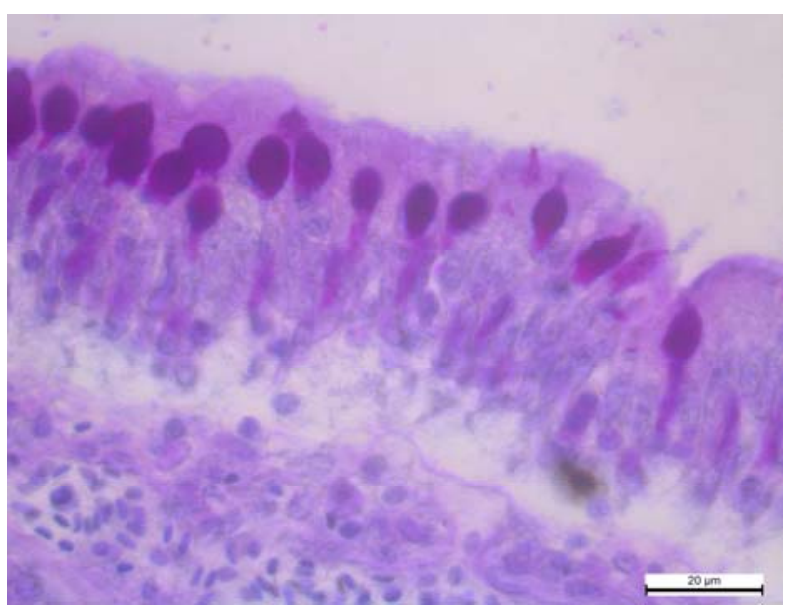

Рис. 14. Ворсинки порожньої кишки курей дослідної групи. Зростання вмісту глікопротеїнів у келихоподібних клітинах. Мак-Манус. Об. 10., ок. 20

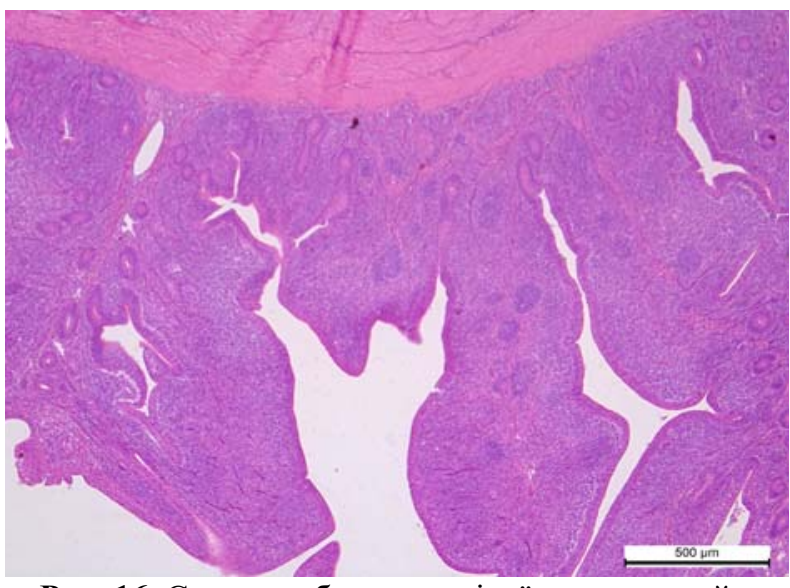

Рис. 16. Слизова оболонка сліпої кишки курейбройлерів дослідної групи. Гематоксилін - еозин. Ок. 10 , об. 10 
За гістоморфометричного дослідження слизової оболонки сліпих кишок на 15 добу досліду відзначали вірогідне зростання на 98,23 мкм висоти ворсинок курей I групи, яка становила 524,34 \pm 14 , мкм, а в контрольній групі - 426,11 \pm 7,87 мкм $(\mathrm{P}<0,05)$. При цьому глибина крипт збільшувалась у I групі на на 4 мкм порівняно з контрольною групою. На 30 і 42 добу згодовування комбікорму з пробіотичними добавками «Probion forte» в дозі 1 г/кг корму, висота ворсинок сліпих кишок курей-бройлерів достовірно збільшувалась у I групі - на 244,41 мкм та 229,3 мкм, а глибина крипт - на 13,85 і 45,02 мкм відповідно, порівняно 3 контрольною групою (рис. 17).

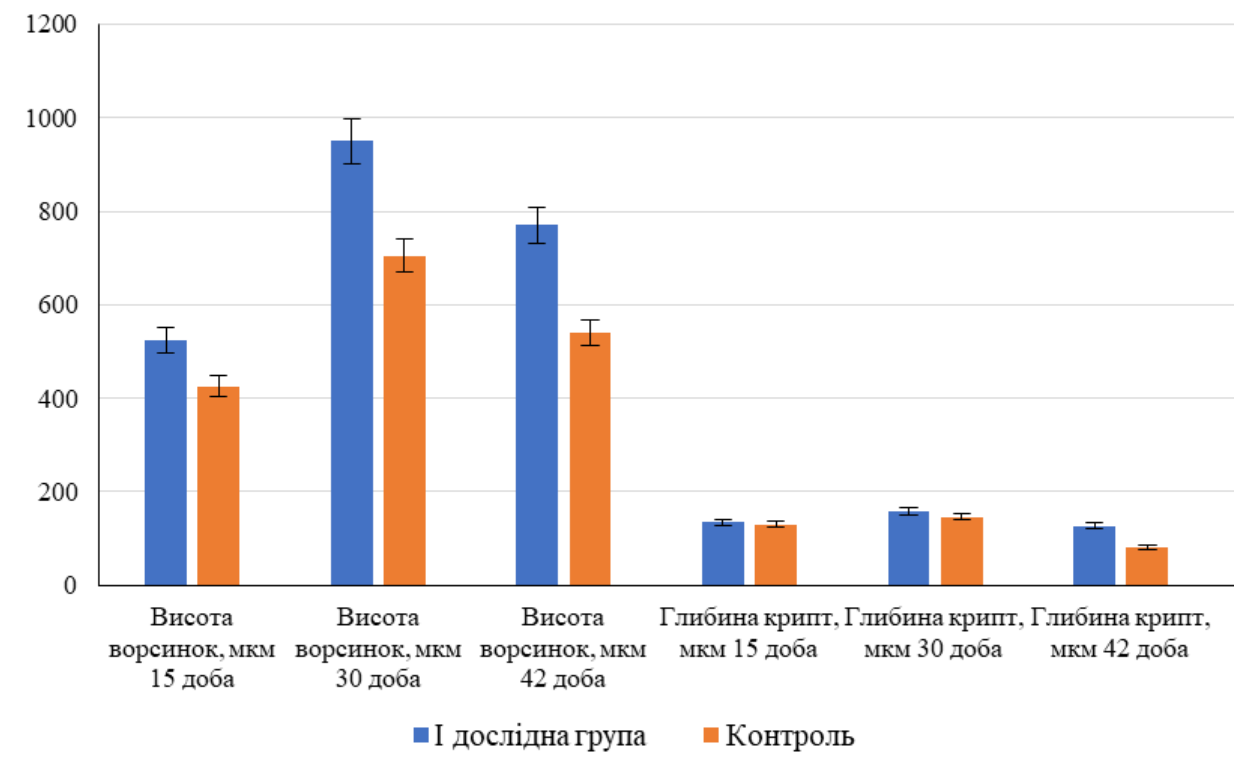

Рис. 17. Гістоморфометричні показники висоти ворсинок та глибини крипт слизової оболонки сліпих кишок на 15, 30 і 42 добу росту і розвитку курей-бройлерів контрольної та дослідної групи

При цьому також відзначали зростання кількості та інтенсивності насиченості цитоплазми келихоподібних клітин барвниками. На препаратах забарвлених альціановим синім за Стідменом у ворсинках та криптах між стовпчастими епітеліоцитами добре проглядались альціанофільні келихоподібні клітини, які в

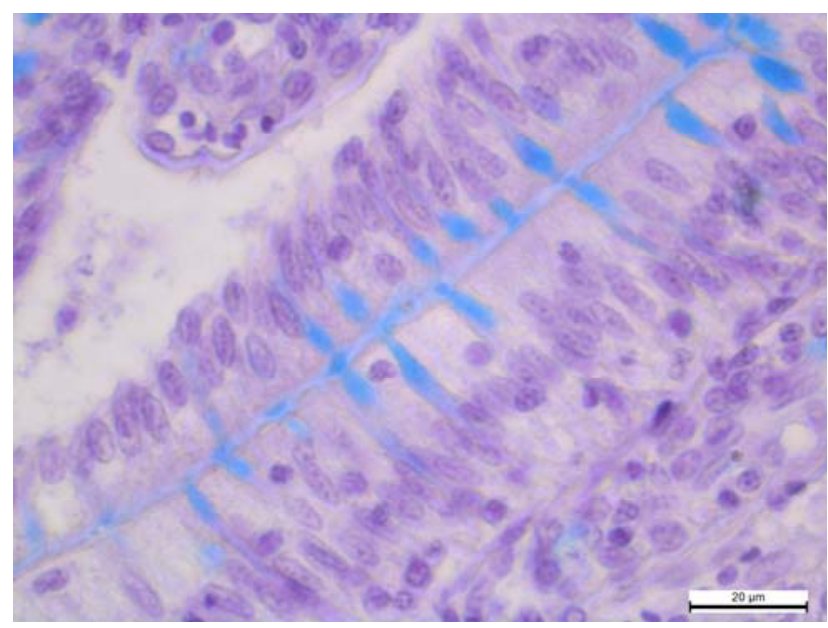

Рис. 18. Альціанофільні, видовженої форми келихоподібних клітин ворсинки сліпої кишки курейбройлерів контрольної групи. Стідмен. Ок. 10, об. 100

На препаратах, забарвлених за Мак-Манусом ворсинок сліпих кишок дослідної груп відзначали збільшення кількості та об'єму келихоподібних клітин та збагачення вмісту цитоплазми PAS-позитивними контрольній групі були видовженої форми, а в дослідній - округлої. Внаслідок інтенсивного нагромадження секреторних продуктів, апікальна поверхня була розширеною, а самі клітини - грушоподібної округлої форми (рис. 18 і 19).

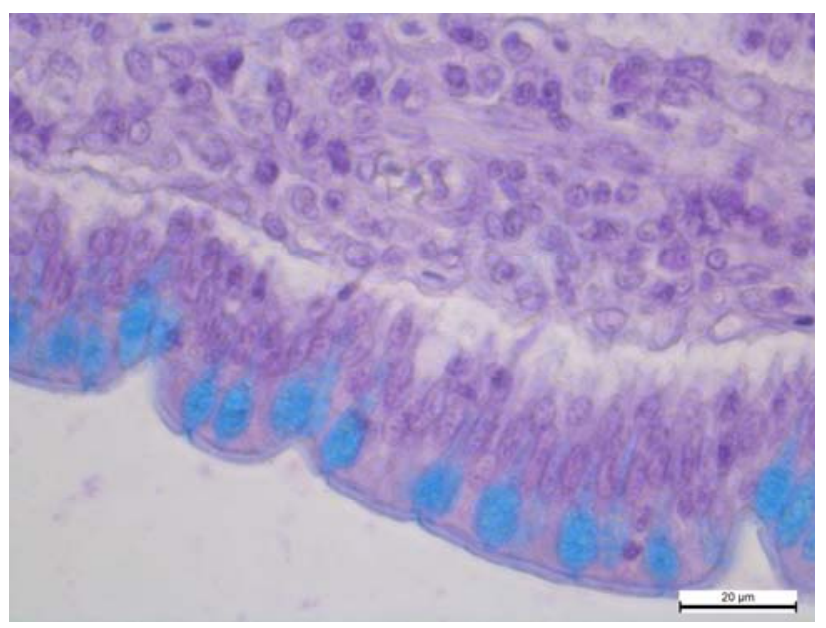

Рис. 19. Альціанофільні, округлої форми келихоподібних клітин ворсинки сліпої кишки бройлерів дослідної групи. Стідмен. Ок. 10, об. 100

речовинами порівняно 3 контрольною групою (рис. 20 i 21).

У гістохімії вуглеводів PAS-реакція відіграє важливу діагностичну роль при ідентифікації полісахаридів, деяких мукополісахаридів і ряду жирних кислот. 
Усі секреторні протеїни зв'язані із вуглеводами та відносяться до складу глікопротеїнів. Слизистий секрет, який обволікає поверхню клітин слугує рідкою

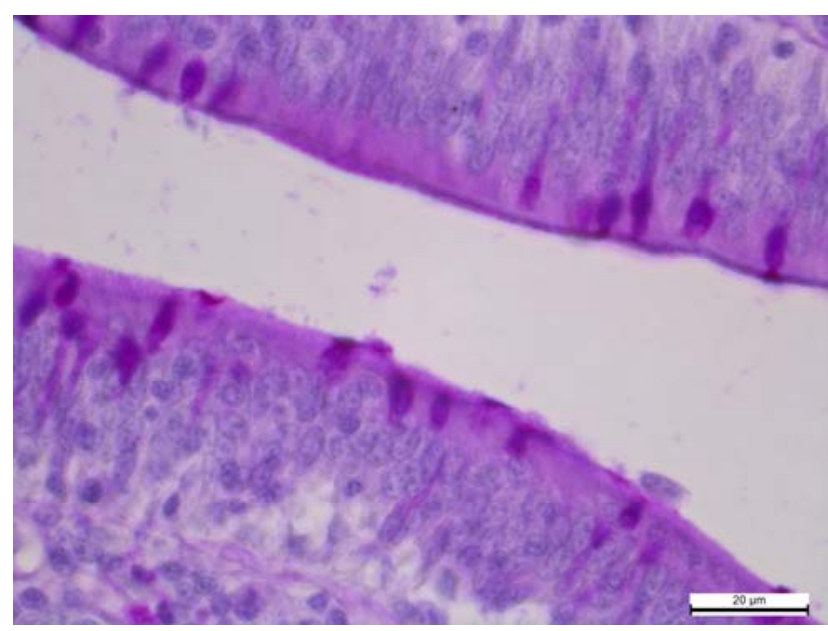

Рис. 20. Фрагмент ворсинки сліпої кишки курей контрольної групи. Видовженої форми келихоподібні клітини. PAS-позитивна реакція. Мак-Манус. Об. 10., ок. 100

Відомо, що мукопротеїди слизової оболонки кишок $є$ складовою частиною захисного апарату клітин, утворюючи біологічно активну поверхню клітин, вони попереджують також автолітичні процеси. Завдяки постійному оновленню поверхневих епітеліальних клітин, нормофлора приепітеліальної плівки, разом $з$ десквамованими ентероцитами, постійно надходить в просвіт кишок і формує домінантну частину порожнинного біоценозу, що активно конкурує 3 потенційно шкідливими факультативними та транзиторними мікроорганізмами, не допускаючи їх надлишкового розмноження і проникнення в приепітеліальну зону (Michael and Hodges, 1973; Guo et al., 2004).

Отже, активне утворення келихоподібними клітинами дванадцятипалої, порожньої та сліпих кишок слизу, багатого глікозаміногліканами та глікопротеїнами сприяло утворенню густої слизистої біоплівки. Мукозні сполуки вкривали поверхневі стінки епітеліальних клітин, крипт, заповнювали простір між ворсинками, що сприяло утворенню потужного бар'єру від проникнення ферментів, патогенної та умовнопатогенної мікрофлори і перешкоджало іiі адгезії та колонізації епітелію.

Аналізуючи результати морфологічних досліджень, слід відзначити, що що найактивніші гіперпластичні та гіпертрофічні процеси проходили в структурних елементах травної трубки курей-бройлерів, яким 40 днів поспіль згодовували з кормами пробіотичну добавку «Probion forte» в дозі 1 г/кг.

\section{Висновки}

1. Застосування «Probion forte» в дозі 1 г/кг 3 кормом курчатам-бройлерам у процесі росту та розвитку сприяло активізаціі мітотичної та синтезувальної функції клітин, активним гіперпластичним та гіпертрофічним процесам структурних елементів слизової фазою в якій проходить рух клітин, а вуглеводи забезпечують вихід білка з клітини (Sreekumar and Hosono, 1998).

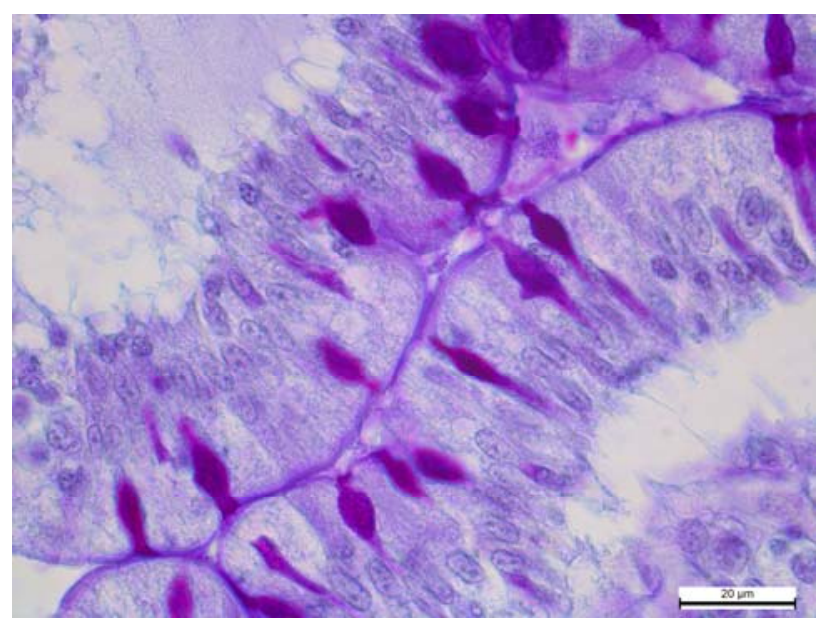

Рис. 21. Фрагмент ворсинки сліпої кишки курей дослідної групи. Грушоподібної форми келихоподібні клітини. PAS-позитивна реакція. Мак-Манус. Об. 10., ок. 100

оболонки дванадцятипалої, порожньої та сліпих кишок курей-бройлерів, що виразилось збільшенням висоти ворсинок та глибини крипт.

2. У курей-бройлерів дослідної групи найвірогідніше збільшувалась висота ворсинок у дванадцятипалій кишці на 15 і 42 доби; у порожній кишці вірогідне збільшення висоти ворсинок відзначали на 15 i 30 доби, а у сліпих кишках - на 30 і 42 доби досліду.

3. Збагачення келихоподібних клітин ворсинок i крипт глікозаміногліканами і глікопротеїнами сприяло активному утворенню слизистої біоплівки, яка $\epsilon$ складовою захисного апарату клітин і потужним бар'єром від проникнення ферментів, патогенної та умовно-патогенної мікрофлори.

4. Висота стовпчастих епітеліоцитів, які розміщувались на ворсинках порожньої кишки тварин I групи становила - 31,5 мкм, а у контролі - 24,9 мкм. Збільшення розмірів та кількості стовпчастих епітеліоцитів, кишкових ендокриноцитів та келехоподібних клітин ворсинок слизової оболонок кишечнику була направлена на покращення пристінкового травлення та всмоктування.

\section{References}

Avtandilov, G.G. (1990). Medicinskaja morfometrija. M.:Medicina (in Russian).

Boiko, N.V. (2008). Kompensatorna mikroflora slyzovykh obolonok $\mathrm{V}$ protsesakh moduliatsii profilaktychnykh ta imunnykh vlastyvostei orhanizmu. «Veterynarna biotekhnolohiia» Biuleten. Materialy mizhnarodnoi naukovo-praktychnoi konferentsii. Kyiv. 13(2), 7-22 (in Ukrainian).

Cummings, J.H., \& Macfarlane, G.T. (2002). Gastrointestinal effects of prebiotics. British Journal of Nutrition. 87(2), 145-151. https://www.ncbi.nlm.nih.gov/pubmed/ 12088511. 
Gardiner, K.R., Erwin, P.J., Anderson, N.H., Barr, J.G., Halliday, M.I., \& Rowlands, B.J. (1993). Colonic bacteria and bacterial translocation in experimental colitis. British Journal of Surgery. 80(4), 512-516. https://www.ncbi.nlm.nih.gov/pubmed/8495325.

Garmaeva, B.C. (2011). Motornaja dejatel'nost' zheludka i kishechnika kur. Veterinarija, 8, 51-52 (in Russian).

Gibson, R.G., \& Roberfroid, M.B. (1995). Dietary modulation of the human colonic microbiota: Introducing the concept of prebiotics. The Journal of Nutrition. 125(6), 1401-1412. https://www.ncbi.nlm. nih.gov/pubmed/ 7782892 .

Guo, F.C., Williams, B.F., Kwakkel, R.P., Li, H.S., Li, X.P., Luo, J.Y., Li, W.K., \& Verstegen, M.W.A. (2004). Effect of mushrooms and herb polysaccharides, as alternatives for an antibiotic, on the cecal microbial ecosystem in broiler chickens. Poultry Science. 83, 175-182. doi: 10.1093/ps/83.2.175.

Horalskyi, L.P., Khomych, V.T., \& Kononskyi, O.I. (2005). Osnovy histolohichnoi tekhniky i morfofunktsionalni metody doslidzhen u normi ta pry patolohii. Navchalnyi posibnyk. Zhytomyr: Polissia (in Ukrainian).

Lilli, R. (1969). Patologicheskaja tehnika i prakticheskaja gistohimija. M.: Mir (in Russian).

Merkulov, G.A. (1961). Kurs patogistologicheskoj tehniki. L.: Izd. med. Literatury (in Russian).

Michael, E., \& Hodges, R.D. (1973). Histochemical changes in the fowl small intestine associated with enhanced absorption after feed rectiction, Histochemie. 36, 39-49. https://link.springer.com/article/10.1007/BF00310120.

Samarcev, A.A., Astanovich, N.I., \& Novik, G.I. (2007). Novye probiotiki dlja zhivotnovodstva. Efektivni kormi ta godivlja. 2(18), 14-15 (in Russian).

Sreekumar, O., \& Hosono, A. (1998). The antimutagenic of properties of a polysaccharide produced by Bifidobacterium longum and its cultured milk against some heterocyclicamines. Canadian Journal of Microbiology. 44(11), 1029-1036. https://www.ncbi.nlm.nih.gov/pubmed/10029998. 